\title{
Aggressive angiomyxoma of the vulva - A rare entity
}

\section{Archana Shivamurthy ${ }^{1}$, Padmapriya Jaiprakash², Paramasivam Lavanya ${ }^{3}$}

${ }^{1}$ Department of Pathology, Melaka Manipal Medical College, Manipal University, Manipal, India, ${ }^{2}$ Department of Pathology, Kasturba Medical College, Manipal University, Manipal, India, ${ }^{3}$ Post graduate student, Kasturba Medical College, Manipal University, Manipal, India

Corresponding author: Dr. Archana Shivamurthy, E-mail: archana_018@yahoo.co.in

\begin{abstract}
Aggressive angiomyxoma (AA) is a rare locally invasive soft tissue tumor that is known for its local recurrence. It affects women of reproductive age group. Clinically it presents as a pedunculated polyp or a polypoidal mass usually involving the pelvis, vulva, vagina and the urinary bladder. Excision is the treatment of choice. Due to its tendency for local recurrence long term follow up is adviced. We present AA in a 43 year old woman involving the vulva.
\end{abstract}

Key words: Aggressive angiomyxoma; Vulva; Polyp

\section{INTRODUCTION}

Aggressive angiomyxoma is a rare, locally invasive, slowly growing, recurrent soft tissue tumor that occurs in women of reproductive age $[1,2]$. It usually involves the pelvis, vulva, perineum, vagina and urinary bladder. Clinically it presents as a pedunculated polyp or a polypoidal mass and needs to be differentiated from other polypoidal lesions that occur at the same site [2-4]. Owing to its high rate of recurrence appropriate management and a close long term clinical follow up is required $[4,5]$.

\section{CASE REPORT}

A 43 year old woman presented with a slowly growing mass in the vulva since 4 months. It was gradually progressive in size and painful. The patient also complained of serous discharge. On examination a polypoidal, spongy mass was present in the vulva measuring $6 \times 4 \mathrm{~cm}$. Skin over the lesion was focally ulcerated. An excision biopsy was performed and the specimen was sent for histopathological examination. On gross examination the skin covered polypoidal, soft nodular mass measured $6.5 \times 4 \times 3.5 \mathrm{~cm}$. Focal the skin surface was ulcerated (Fig. 1). Cut section revealed myxoid areas with focal cystic areas (Fig. 2). On histopathological examination, focally ulcerated stratified squamous epithelium was observed overlying tumor composed of spindle to stellate cells with ill-defined cytoplasm in a fibrocollagenous myxoid stroma, interspersed varying sized blood vessels ranging from small thin walled capillaries to thick walled dilated, congested blood vessels (Figs. 3 and 4), few showing perivascular hyalinization and lymphocytic infiltrate (Fig. 5). Hence a diagnosis of aggressive angiomyxoma was rendered.

\section{DISCUSSION}

AA was initially described by Steeper and Rosai in 1983 [1,2]. The aggressive nature of the lesion is explained by its local invasiveness and tendency for recurrence. It has a very low propensity for metastasis and few cases of metastasis to the lung have been reported in literature. Angiomyxomas are classified either as superficial (cutaneous myxoma) or AA [5,6]. The former occur in middle aged adults, involving the head and neck region presenting as polyps or nodules. On histopathology, the lesion shows edematous stroma with myxoid material. The latter occurs exclusively in the perineal and pelvic regions of women during re reproductive years. Occasionally it has been reported in men [6,7].

AA are hormonally responsive tumors. Estrogen and progesterone receptors are commonly found to be positive.

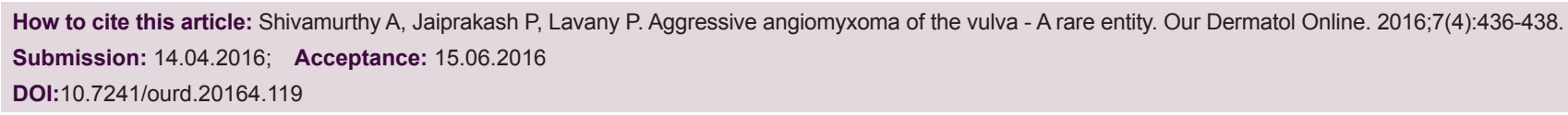




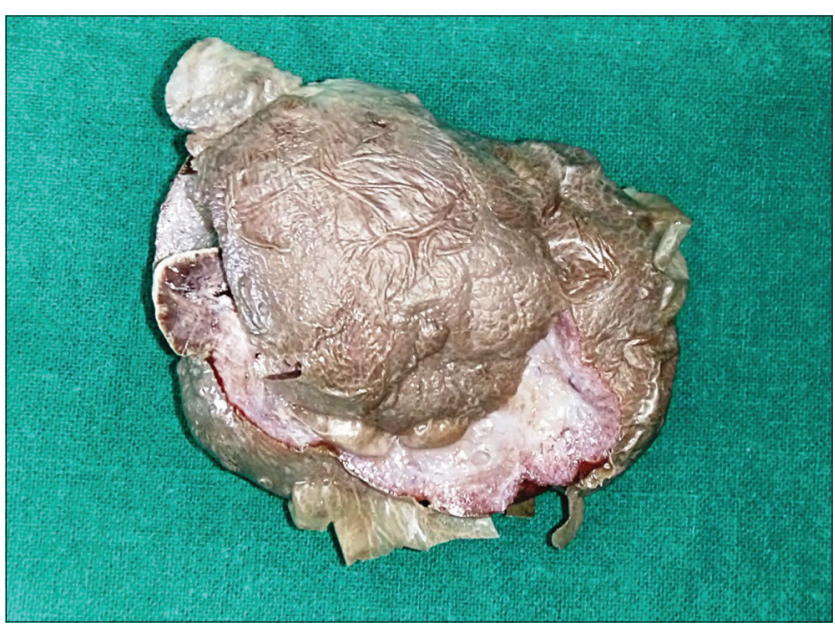

Figure 1: Gross photograph showing a polypoidal skin coversed nodular tissue mass.

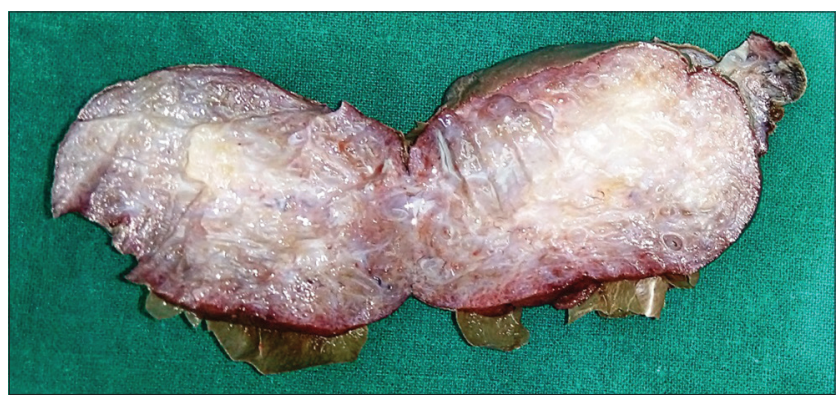

Figure 2: Gross photograph showing cut section with myxoid areas and focal cystic areas.

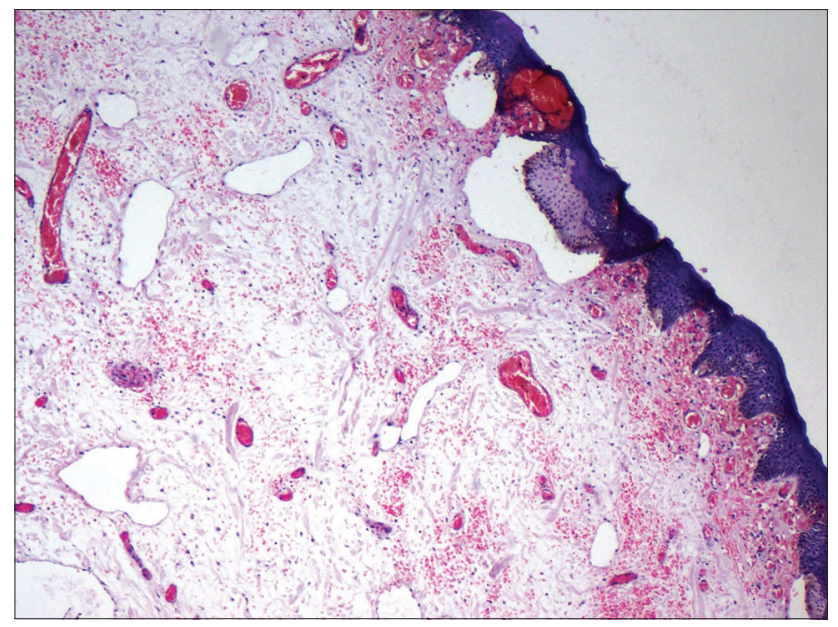

Figure 3: Stratified squamous epithelium overlying tumor composed of spindle to stellate cells in a fibrocollagenous myxoid stroma [H \& E x40].

The origin of this tumor has been attributed to specialized mesenchymal cells present in the pelvic-perineal region and the multipotent perivascular progenitor cells, which often display both myofibroblastic and fibroblastic features $[4,7]$. This had been substantiated with the tumor cells expressing desmin and, in some cases, a smooth muscle actin. A variety of molecular

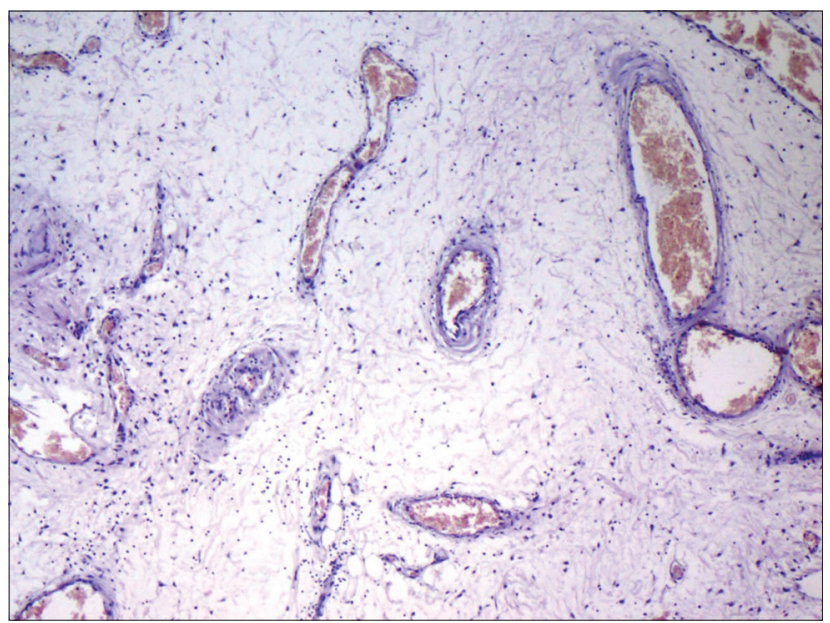

Figure 4: Interspersed varying sized blood vessels ranging from small thin walled capillaries to thick walled dilated, congested blood vessels [H \& E x40].

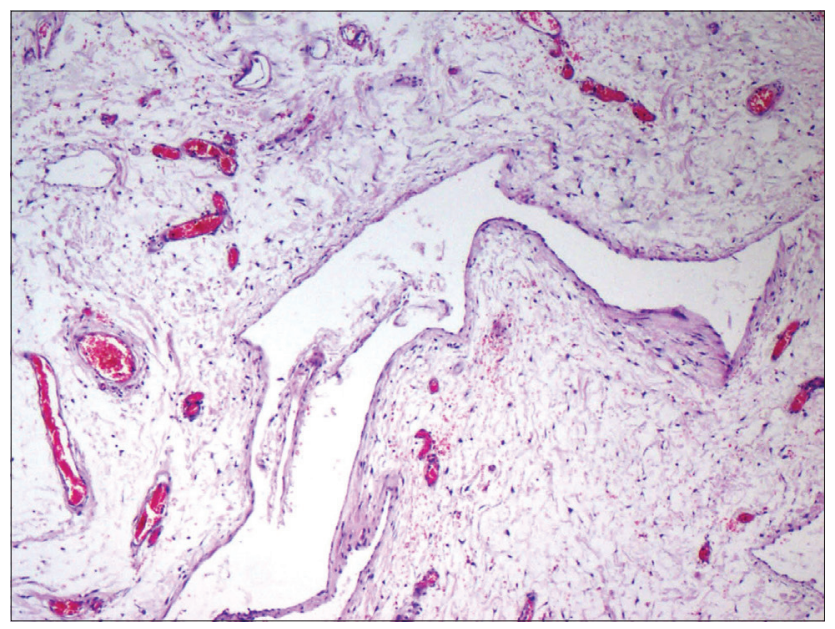

Figure 5: Perivascular hyalinization and lymphocytic infiltrate [H\& Ex100].

genetic alterations have been identified involving the chromosome 12, in the region 12q13-15 [7,8]. It has been described that high-mobility group protein isoform I-C (HMGIC) gene, which encodes proteins involved in the transcriptional regulation, plays a role in the pathogenesis of this tumor. Immunohistochemical detection using anti HMGI-C antibody can also be used for detection of residual disease $[4,7,8]$.

On microscopy AAs show widely separated spindleshaped neoplastic cells in a loose myxoid stroma rich in collagen fibers, hyaluronic acid, along with prominent irregular-shaped blood vessels. The myxoid stroma is also sometimes weakly positive with alcian blue at pH $2.5[6,8]$. Immunohistochemically, the tumor cells are positive for vimentin and may stain for smooth muscle actin and desmin. The differential diagnosis of AA included myxomas, angiomyofibroblastoma, fibroepithelial stromal polyp, superficial angiomyxoma, 
Table 1: Differential diagnosis of aggressive angiomyxoma

\begin{tabular}{|c|c|c|c|}
\hline Lesions & Sites & Age & Histopathological features \\
\hline $\begin{array}{l}\text { Fibroepithelial stromal } \\
\text { polyp }\end{array}$ & $\begin{array}{l}\text { Vagina, } \\
\text { vulva }\end{array}$ & Adult women during pregnancy & $\begin{array}{l}\text { Central fibrovascular core covered by normal appearing squamous epithelium without } \\
\text { intervening grenz zone, edematous stroma with hypocellular or myxoid areas. } \\
\text { May have atypical stromal cells including stellate and multinucleated cells }\end{array}$ \\
\hline Angiomyofibroblastoma & $\begin{array}{l}\text { Vagina, } \\
\text { vulva }\end{array}$ & $\begin{array}{l}\text { Middle aged females (fourth } \\
\text { and fifth decades of life) }\end{array}$ & $\begin{array}{l}\text { Encapsulated tumor with hyper- and hypocellular areas and numerous vessels } \\
\text { Vessels may be hyalinized } \\
\text { Hypercellular areas composed of plump stromal cells that often congregate around } \\
\text { vessels } \\
\text { Hypocellular areas are more spindled } \\
\text { Rarely mitotic figures and multinucleated cells }\end{array}$ \\
\hline $\begin{array}{l}\text { Superficial } \\
\text { angiomyxoma }\end{array}$ & Perineum & $2^{\text {nd }}$ decade & $\begin{array}{l}\text { Frequently multinodular, long thin walled vessels, stromal neutrophils } \\
\text { Frequently involves subcutis } \\
\text { Paucicellular }\end{array}$ \\
\hline Myxoid neurofibroma & vulva & $\begin{array}{l}\text { Young patients with Von } \\
\text { Recklinghausen's disease }\end{array}$ & $\begin{array}{l}\text { Bundles of wavy and spindle cell with palisade arrangement, intervening few collagen } \\
\text { fibers, areas of mucoid degeneration }\end{array}$ \\
\hline Sarcoma botryoides & Vulva & Childhood and young adulthood & $\begin{array}{l}\text { Hypercellular zone immediately beneath epithelium (Nicholson's cambium } \\
\text { layer - resembles hypercellular zones that produce growth rings in trees) } \\
\text { Cells are undifferentiated, round or spindled with minimal cytoplasm, frequent mitotic } \\
\text { figures } \\
\text { Less cellular in deeper layers, composed of differentiating and undifferentiated cells }\end{array}$ \\
\hline
\end{tabular}

myxoid neurofibroma, myxoid liposarcoma, myxoid variant of malignant fibrous histiocytoma, sarcoma botryoides and myxofibrosarcoma $[9,10]$ (Table 1).

Clinical differential diagnosis includes bartholin cyst, labial cyst, gartner duct cyst, lipoma, levator hernia or sarcoma $[6,7]$. The treatment of choice is wide surgical excision. Recurrences may occur from a few months to several years after excision ranging from 2 months to 15 years. Hence patients need to have long term follow up [4,9]. Incomplete resection is acceptable where fertsility is to be preserved as local recurrences can be treated with further resection. Tamoxifen, raloxifene and gonadotropin-releasing hormone analogues can be used to reduce the tumor size, thus helping to make complete excision feasible in large tumors $[7,10]$. They are also used in the treatment of recurrence. The present patient has been kept on close follow. No recurrence has been noted in the last 6 months.

\section{CONCLUSION}

$\mathrm{AA}$ is a locally invasive tumor that probably arises from the common pluripotential primitive cell located around the vessels of connective tissue. Recurrence is known to occur. Hence long term follow up of these patients is mandatory.

\section{Consent}

The examination of the patient was conducted according to the Declaration of Helsinki principles.

\section{REFERENCES}

1. Alameda F, Munne A, Baro T, Iglesias M, Condom E, Lloreta-Trull J, et al. Vulvar angiomyxoma, aggressive angiomyxoma and angiomyofibroblastoma: An immunohistochemical and ultrastructural study. Ultrastruct Pathol. 2006;30:193-205.

2. Nucci MR, Fletchr CD. Vulvovaginal soft tissue tumors: Update and review. Histopathology. 2000;36:97-108.

3. Blandamura S, Cruz J, Faure-Vergara L, Machado-Puerto I, Ninfo V. Aggressive angiomyxoma: A second case of metastasis with patient's death. Hum Pathol. 2003;34:1072-4.

4. Behranwala KA, Thomas JM. Aggressive angiomyxoma: A distinct clinical entity. Eur J Surg Oncol. 2003;29:559-63.

5. McCluggage WG, Jamieson T, Dobbs SP, Grey A. Aggressive angiomyxoma of the vulva: Dramatic response to gonadotropinreleasing hormone agonist therapy. Gynecol Oncol. 2006;100:623-5.

6. Magtibay PM, Salmon Z, Keeney GL, Podratz KC. Aggressive angiomyxoma of the female pelvis and perineum: A case series. Int J Gynecol Cancer. 2006;16:396-401.

7. Schoolmeester JK, Leifer AJ, Wang L, Hameed MR. Vulvar myxoid liposarcoma and well differentiated liposarcoma with molecular cytogenetic confirmation: case reports with review of malignant lipomatous tumors of the vulva. Int J Gynecol Pathol. 2015;34:390-5

8. Srinivasan R, Mohapatra N, Malhotra S, Rao SK. Aggressive angiomyxoma presenting as a vulval polyp. Indian J Cancer. 2007;44:87-9.

9. Mandal S, Dhingra K, Roy S, Khurana N. Aggressive angiomyxoma of the vulva presenting as a pedunculated swelling.Indian J Pathol Microbiol. 2008;51:259-60.

10. Salman MC, Kuzey GM, Dogan NU, Yuce K. Aggressive angiomyxoma of vulva recurring 8 years after initial diagnosis. Arch Gynecol Obstet. 2009;280:485-7.

Copyright by Archana Shivamurthy, et al. This is an open access article distributed under the terms of the Creative Commons Attribution License, which permits unrestricted use, distribution, and reproduction in any medium, provided the original author and source are credited.

Source of Support: Nil, Conflict of Interest: None declared. 